\title{
Characterization of the mucosal and systemic immune response induced by CrylAc protein from Bacillus thuringiensis HD 73 in mice
}

\section{R.I. Vázquez-Padrón ${ }^{1}$, \\ L. Moreno-Fierros², \\ L. Neri-Bazán ${ }^{3}$, \\ A.F. Martínez-Gill, \\ G.A. de-la-Riva ${ }^{1}$ \\ and R. López-Revilla ${ }^{3}$}

\author{
${ }^{1}$ Center for Genetic Engineering and Biotechnology, Havana, Cuba \\ ¿U nidad de M orfología y Función Iztacala, Universidad Autónoma de M éxico, \\ Tlalnepantla, Edo M exico, M exico \\ ${ }^{3}$ Department of Cell Biology, Cinvestav-IPN, M exico, DF
}

\section{Correspondence \\ R.I. Vázquez-Padrón \\ Center for Genetic Engineering \\ and Biotechnology (CIGB) \\ P.O. Box 6162 \\ 10600 Havana \\ Cuba \\ Fax: + 53-7-21-8070/33-6008 \\ E-mail: roberto.vasquez@ cigb.edu.cu \\ Presented at the XXVIII Annual Meeting of the Brazilian Society of Biochemistry and Molecular Biology, Caxambu, MG, Brasil, May 22-25, 1999. \\ Research partially supported by Conacyt grants (N os. 0797-3453 PN and 5106-M 9406)}

Received October 7, 1999 Accepted November 4, 1999

\begin{abstract}
The present paper describes important features of the immune response induced by the Cry1 Ac protein from Bacillus thuringiensis in mice. The kinetics of induction of serum and mucosal antibodies showed an immediate production of anti-Cry $1 \mathrm{Ac}$ IgM and IgG antibodies in serum after the first immunization with the protoxin by either the intraperitoneal or intragastric route. The antibody fraction in serum and intestinal fluids consisted mainly of IgG1. In addition, plasma cells producing anti-Cry1 Ac IgG antibodies in Peyer's patches were observed using the solid-phase enzyme-linked immunospot (ELISPOT). Cry1Ac toxin administration induced a strong immune response in serum but in the small intestinal fluids only anti-Cry $1 \mathrm{Ac}$ IgA antibodies were detected. The data obtained in the present study confirm that the Cry1 Ac protoxin is a potent immunogen able to induce a specific immune response in the mucosal tissue, which has not been observed in response to most other proteins.
\end{abstract}

\section{Introduction}

Bacillus thuringiensis $(\mathrm{Bt})$ is a gram-positive soil bacterium widely used in agriculture as a biological pesticide. During sporulation, bacterial cells synthesize insecticidal inclusion bodies consisting of proteins (Cry proteins) active against larvae of invertebrates species (1). Cry proteins can be found in nature in three major forms: crystalline, soluble protoxin and soluble toxin.

Protoxins are the subunits of crystals which, when treated with a trypsin-like protease, release the active toxin. Cry protoxins have a high molecular weight (70-140 kDa) and are soluble at alkaline $\mathrm{pH}$. In contrast, Cry toxins have moderate molecular weights (40-70 kDa) and are resistant to proteolysis and stable at extreme $\mathrm{pH}$ (2). Little is known about the physiological or immunological effects of the Cry protein family on vertebrate organisms, despite the proven homology of Bt with the pathogenic Bacillus cereus species (3).

The few studies concerning the immunological properties of Cry protein have been limited to protoxin. In previous reports, Prasad and Shethna $(4,5)$ suggested that these pro- 
teins have antitumoral activity against Yoshida ascites sarcoma in rats (4) and enhance the immune response to sheep red blood cells (5). Recently, we demonstrated that recombinant Cry $1 \mathrm{Ac}$ protoxin (pCry1 Ac) administered to mice by the intraperitoneal (ip) or intragastric (ig) route induces systemic and mucosal antibody responses similar to those obtained with cholera toxin (6). Moreover, in adjuvanticity studies, pCry $1 \mathrm{Ac}$ elicited serum antibodies against hepatitis B surface antigen and BSA when these antigens were coadministered ig, and IgG antibodies in the intestinal fluid when the antigens were administered ip (7).

The use of Bt-based products is increasing because they are safe to the environment and to vertebrate organisms. A new generation of biopesticides, transgenic plants containing significant amounts of Cry toxin, has been commercialized and used for food production (8). However, there are no studies about the immunological or immunotoxicological properties of Cry toxins.

In this investigation, important features of the immune response induced by $\mathrm{pCry} 1 \mathrm{Ac}$ in mice were studied. The kinetics of serum and mucosal anti-pCry1 Ac antibody response is described in detail and the subclass of IgG antibodies induced by the protoxin is determined. The characterization of anti-pCry $1 \mathrm{Ac}$ antibody-producing cells present in several lymphoid organs after immunization was performed using the solid-phase enzymelinked immunospot (ELISPOT). The study of Cry1 Ac toxin (tCry1 Ac) immunogenicity was also one of the aims of this work.

\section{Material and Methods}

\section{O rganisms and culture conditions}

Dr. Donald Dean, Ohio State University, Columbus, generously provided the Escherichia coli JM103 strain (pOS9300). The recombinant strain was grown in LB medium containing $50 \mu \mathrm{g}$ ampicillin per $\mathrm{ml}$ and
pCry1Ac production was induced with isopropyl B-D-thiogalactopyranoside (IPTG) (9).

\section{Immunogens}

Recombinant Cry1 Ac protoxin was purified from IPTG-induced pOS9300 cultures (9). The cell pellet harvested by centrifugation was resuspended in TE buffer $(50 \mathrm{mM}$ Tris$\mathrm{HCl}, \mathrm{pH} \mathrm{8,50} \mathrm{mM} \mathrm{EDTA)} \mathrm{and} \mathrm{sonicated}$ (Fisher Sonic Dismembrator Model 300, CA, USA) three times for $5 \mathrm{~min}$ on ice. Inclusion bodies were collected by centrifugation at $10,000 \mathrm{~g}$ for $10 \mathrm{~min}$. The pellets were washed twice with TE buffer and pCry1 Ac solubilized in CBP buffer $\left(0.1 \mathrm{M} \mathrm{Na}_{2} \mathrm{CO}_{3}\right.$, $\mathrm{pH} 9.6,1 \% 2$ mercaptoethanol, and $1 \mathrm{mM} \mathrm{pMSF}$ ). The particulate material was separated by centrifugation. tCry1 Ac was obtained by trypsin digestion of the recombinant protoxin (10). Purified proteins were examined by SDS-PAGE (11), and protein concentration was determined by the method of Bradford (12).

\section{Immunizations}

In all experiments, 8-10-week-old female $\mathrm{BALB} / \mathrm{c}$ mice were used. Immunizations were carried out according to Coligan et al. (13). The antigens were administered ip in $0.1 \mathrm{ml}$ phosphate-buffered saline (PBS) and ig in $0.1 \mathrm{ml}$ magnesium-aluminum hydroxide suspension $\left(\right.$ Maalox ${ }^{\circledR}$, Ciba-Geigy, Mexico City, Mexico). Experimental groups consisted of five animals to which three antigen doses containing $100 \mu \mathrm{g}$ of pCry $1 \mathrm{Ac}$ or tCry1 Ac were applied on days 0,7 and 14 . Nonimmunized mice, used as control, were randomly selected from the animal group and maintained under similar conditions. Mice were sacrificed 7 days after the last immunization.

\section{Sample collection}

Serum samples were obtained from blood extracted by cardiac puncture of chloroform- 
anesthetized mice. Fresh feces were harvested from live mice and pooled for each group (14). Subsequently, $1 \mathrm{~g}$ of feces was resuspended in $600 \mu 1$ of ice-cold PBSM buffer (5\% nonfat milk in PBS) containing $100 \mathrm{mM}$ pMHB, particulate material was discarded by centrifugation and supernatants were stored at $-20^{\circ} \mathrm{C}$.

To collect the intestinal fluid (15), the intestinal tract was closed by tying it with surgical suture at the level of the duodenum and rectum; two closely spaced sutures were also placed around the cecum. The peritoneal cavity was washed with cold PBS and the intestinal tract excised and placed on a Petri dish containing $20 \mathrm{ml}$ of cold PBSM. The large and small intestines were separated by cutting between the two cecal threads and separately washed twice with $10 \mathrm{ml}$ PBSM to remove contaminating tissues and blood. With the small intestine held at the duodenum level, the knot was loosened and a cannula introduced. The small intestine was filled with $5 \mathrm{ml}$ PBSM and flushed at the ileal end by loosening the knot. The content was squeezed into a sterile Petri dish containing $0.5 \mathrm{ml}$ of $100 \mathrm{mM}$ pHMB dissolved in PBS. The same procedure was performed with the large intestine by introducing the cannula into the rectum and flushing the contents with $3 \mathrm{ml}$ of cold PBS through the tip of the cecum. Flushed intestinal contents were centrifuged for $10 \mathrm{~min}$ at $13,000 \mathrm{~g}$ and the supernatants stored at $-20^{\circ} \mathrm{C}$. To determine possible blood contamination in the intestinal fluids and feces, hemoglobin content was assayed by the Accuglobulin Hemoglobin standard test (Ortho Diagnostic Systems, Rantan, NJ, USA) and with Combur test reactive strips (Boehringer-Mannheim, Mannheim, Germany).

\section{ELISA}

Antibody levels in sera and intestinal fluids were determined by ELISA (13). Briefly, 96-well plates were coated with 10 $\mu \mathrm{g} / \mathrm{ml}$ of either pCry1 Ac or tCry $1 \mathrm{Ac}$ in carbonate buffer. Plates were incubated $2 \mathrm{~h}$ at $37^{\circ} \mathrm{C}$ and blocking was performed with PBSMT ( $1 \%$ nonfat dry milk and $0.05 \%$ Tween 20 in PBST). Sera and small and large intestine fluids were serially diluted with ice-cold PBSMT and $100 \mu 1$ volumes were added to the microwells. The plates were incubated overnight at $4{ }^{\circ} \mathrm{C}$, washed with PBST and then anti-IgG, anti-IgM (Pierce, Rockford, IL, USA) or anti-IgA (Sigma Chemical Co., St. Louis, MO, USA) secondary antibodies (peroxidase-labeled goat anti-mouse) were added. To determine the IgG class, a secondary antibody (peroxidase-labeled goat anti-mouse antibody) specific for total IgG, IgG1, IgG2a, IgG2b or IgG3 (Boehringer-Mannheim) was added. The enzymatic reaction was started by the addition of substrate solution $(0.5 \mathrm{mg} / \mathrm{ml} \mathrm{o-}$ phenylenediamine and $0.01 \% \mathrm{H}_{2} \mathrm{O}_{2}$ in 0.05 $\mathrm{M}$ citrate buffer, $\mathrm{pH}$ 5.2) and stopped with $2.5 \mathrm{~N} \mathrm{H}_{2} \mathrm{SO}_{4}$. The absorbance at $492 \mathrm{~nm}$ $\left(\mathrm{A}_{492}\right)$ was measured using an ELISA Multiskan reader (Anthos Labtec Instruments, Los Angeles, CA, USA). The background was established as the dilution of serum or intestinal fluid from nonimmunized mice with the highest $\mathrm{A}_{492}$. Titers were defined as the reciprocal of the highest endpoint sample dilution with an $\mathrm{A}_{492}$ value 0.1 higher than that of the background. The levels of specific antibodies in the intestinal fluid were calculated from the corresponding $\mathrm{A}_{492}$ values.

\section{Cell isolation}

Lymphoid cells from spleen (Spl), mesenteric lymph nodes (MLN) and Payer's patches (PP) were prepared by teasing the corresponding tissues through a grid (16).

Intestinal lamina propria (LP) lymphocytes were prepared as previously described (17). The intestines were washed by flushing with cold RPMI medium. PP were removed from the small intestine and the small and 
large intestines were separately everted by introducing a plastic cannula with a string inside. The everted large or small intestine was then incubated for $30 \mathrm{~min}$ at $37^{\circ} \mathrm{C}$ in RPMI medium supplemented with $1 \%$ fetal calf serum (FCS), $100 \mu \mathrm{g} / \mathrm{ml}$ gentamycin and $0.005 \mathrm{M}$ EDTA. The intestinal mucosa was gently compressed with a syringe plunger through a plastic mesh and washing several times with RPMI-1\% FCS. The intestines, without epithelial and intraepithelial cells, were then incubated with $10 \mathrm{ml}$ of RPMI-1\% FCS supplemented with $60 \mathrm{U} / \mathrm{ml}$ of collagenase. The intestine was again gently compressed on the mesh and the cell suspension, containing LP lymphocytes, was placed on ice. Isolated cells were washed twice in RPMI-1\% FCS and diluted in RPMI-10\% FCS. Cell viability and counts were determined by the Trypan blue exclusion test (18).

\section{ELISPOT assay}

Individual cells secreting anti-pCry $1 \mathrm{Ac}$ antibodies were enumerated by the ELISPOT technique (19). Briefly, nitrocellulose discs were placed on the bottom of a polystyrene culture plate and coated with $10 \mu \mathrm{g} / \mathrm{ml}$ pCry1Ac in carbonate buffer. The wells were blocked with PBSMT and the plates washed repeatedly with PBST. At this point, $500 \mu 1$ of a cell suspension $\left(10^{5}-10^{6}\right.$ cells $\left./ \mathrm{ml}\right)$ in RPMI medium was added to wells and incubated for $4 \mathrm{~h}$ at $37^{\circ} \mathrm{C}$, under $8 \% \mathrm{CO}_{2}$ and $90 \%$ relative humidity. After washing with PBST, an anti-IgG, anti-IgM or anti-IgA (peroxidase-labeled goat anti-mouse) secondary antibody was added and the plate was incubated at room temperature for $2 \mathrm{~h}$. Finally, $500 \mu \mathrm{l}$ of substrate solution $(0.01 \mathrm{mg} / \mathrm{ml} 3,3-$ diaminobenzidine, $10 \mathrm{mg} / \mathrm{ml}$ nickel chloride, $10 \mathrm{mg} / \mathrm{ml}$ cobalt chloride and $0.005 \%$ $\mathrm{H}_{2} \mathrm{O}_{2}$ ) was added to each well. Spot-forming cells (SFC) were enumerated under stereomicroscope at low magnification and the data are reported as the SFC per $10^{7}$ cells found in three membranes.

\section{Calculations and statistics}

Titers and SFC values were converted to logarithms for calculation of arithmetic means, standard deviation and rank. The significance of differences between groups was tested using the Mann-Whitney test and the differences observed were determined by the Newman-Keuls test (20).

\section{Results}

\section{Kinetics of systemic and mucosal anti-pCry1Ac antibody responses}

Anti-pCry1 Ac IgG and IgM antibodies were detectable in serum immediately after the first immunization with $100 \mu \mathrm{g}$ pCry $1 \mathrm{Ac}$ by the ip or ig route (Figure 1). The production of antibodies continued to increase after the third dose on day 14. By day 21, the antipCry $1 \mathrm{Ac}$ IgG antibody titer reached a plateau and did not change significantly until the end of the study on day 126 . In contrast, the levels of anti-pCry1 Ac IgM antibodies in serum fell by day 21 while IgA antibodies rose to the maximal level. The IgA specific antibodies were detectable in serum of immune mice up to 66 days after the last immunization. The serum antibody titers induced by pCry1Ac injected ip were higher than those obtained after ig administration. However, the kinetic curves for serum antibody induction were similar by both immunization routes.

The induction of a mucosal immune response was indirectly measured in fresh feces from immune mice (Figure 1). The feces were free of hemoglobin, as tested with reactive strips. After the first immunization, antipCry 1 Ac IgG coproantibodies were detected in feces from animals immunized $i p$, with levels rising to maximal values by day 21 . However, seven days later the IgG antibody titer dropped ten times to a basal value which 
remained unchanged up to the end of the experiment. In this experimental group, IgA specific antibodies were detected on day 36 . When the antigen was administered ig, coproantibody levels in feces were lower than those obtained in mice immunized $i p$, although significant IgG and IgA coproantibody levels were observed from day 14 to the end of the experiment. IgM specific antibodies were not detected in feces. Nonimmunized mice did not show antiCry1 Ac antibodies in serum or feces.

\section{Anti-pCry1Ac IgG antibody subclass}

The titers induced by pCry1Ac injected ip were 4.50 for IgM, 5.9 for IgG and 3.11 for IgA. The IgG serum antibodies were mainly IgG1 (5.37) although titers of 4.60, 4.58 and 4.02 were found for IgG2a, IgG2b and IgG3 subclasses, respectively (Figure 2).

The anti-pCry $1 \mathrm{Ac}$ antibody titers obtained were 2.44 for IgM, 5.17 for IgG and 3.2 for IgA when the protoxin was administered ig. The IgG antibody titers were 3.98 ( $\operatorname{IgG} 1$ ), 3.28 (IgG2b), 3.75 (IgG3). In contrast to the ip route, ig administration of pCry1 Ac did not induce specific IgG2a antibodies in se- rum (Figure 2).

High levels of IgG anti-pCry1 Ac coproantibodies were induced in the fluids of the small and large intestines using the ip route, whereas moderate intestinal $\operatorname{IgA}$ and $\operatorname{IgG}$ antibody responses were obtained by the $i g$ route. The anti-pCry $1 \mathrm{Ac}$ IgG antibody fraction in the small and large intestine fluids from mice immunized ip mainly contained IgG1, although significant levels of IgG2a and IgG3 antibodies were also found. Administration of the antigen by the ig route mainly induced IgG1 antibodies in the fluids of both intestines (Figures 3 and 4). Serum and mucosal anti-pCry1 Ac antibodies were not detected in nonimmunized mice. The intestinal contents did not show the presence of hemoglobin.

\section{Induction of pCrylAc-specific antibody-producing cells}

To determine the distribution of $\mathrm{B}$ cells capable of secreting anti-pCry1 Ac antibodies, the ELISPOT technique was applied to cells isolated from different lymphoid organs seven days after the last immunization. The application of pCry1 Ac by the ip route
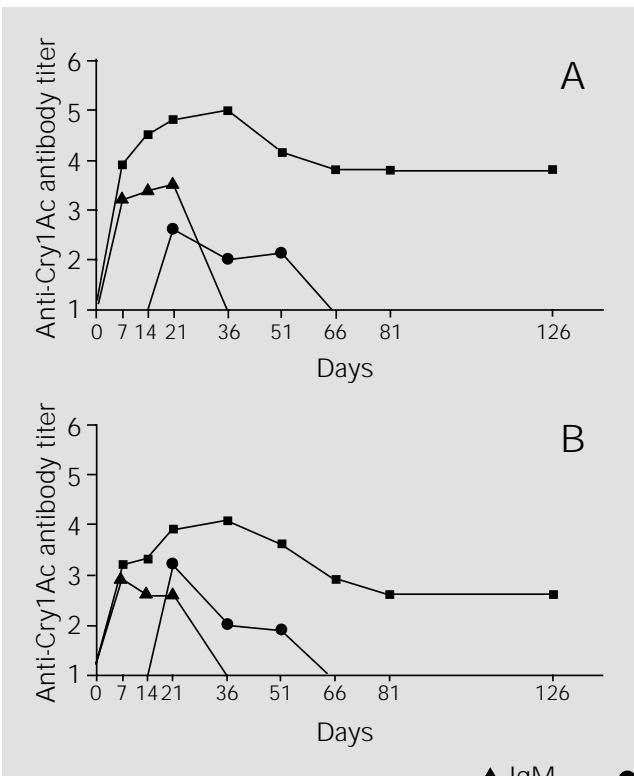

$\Delta$ lgM
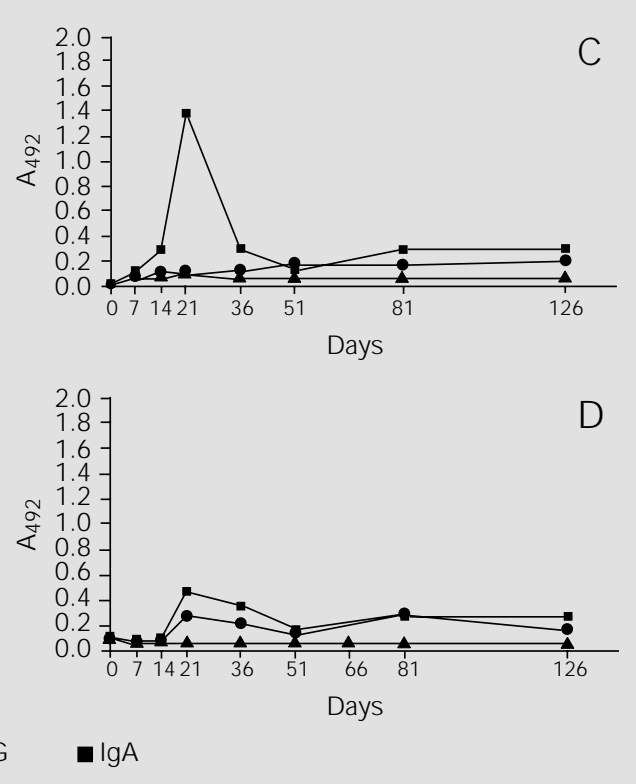

Figure 1 - Kinetics of serum (A and $B$ ) and intestinal (C and D) anti-pCrylAc antibody production. Mice were immunized with $100 \mu \mathrm{g}$ of pCrylAc by the ip (A and $C$ ) or ig ( $B$ and $D$ ) route. Sera and feces from five mice were pooled and the IgM (triangles), IgG (circles) and IgA (squares) antibody contents were determined by ELISA. Nonimmunized mice showed antibody titers $<1$ in serum and $A_{492}<1$ in fecal extracts. 
Figure 2 - Subclasses of serum anti-pCrylAc IgG antibodies induced after ip or ig immunization with $100 \mu \mathrm{g}$ of pCrylAc. Nonimmunized mice showed serum antibody log-titers $<1$. Bars represent the mean \pm SD titers for each experimental group $(\mathrm{N}=5)$. The letters on top of the bars represent the differences observed by the Newman-Keuls test $(\mathrm{P}<0.01)$
Figure 3 - Subclasses of antipCrylAc IgG coproantibodies in the large intestine fluids after ip or ig immunization with $100 \mu \mathrm{g}$ of pCrylAc. The mean $\mathrm{A}_{492}$ val$0.091 \pm 0.012$. Bars represent the level of antibodies reported as arbitrary units of $A_{492} \pm S D$ for each experimental group ( $\mathrm{N}$ $=5$ ). The letters on top of the bars represent the differences observed by the Newman-Keuls test $(P<0.01)$. ues of nonimmunized mice were
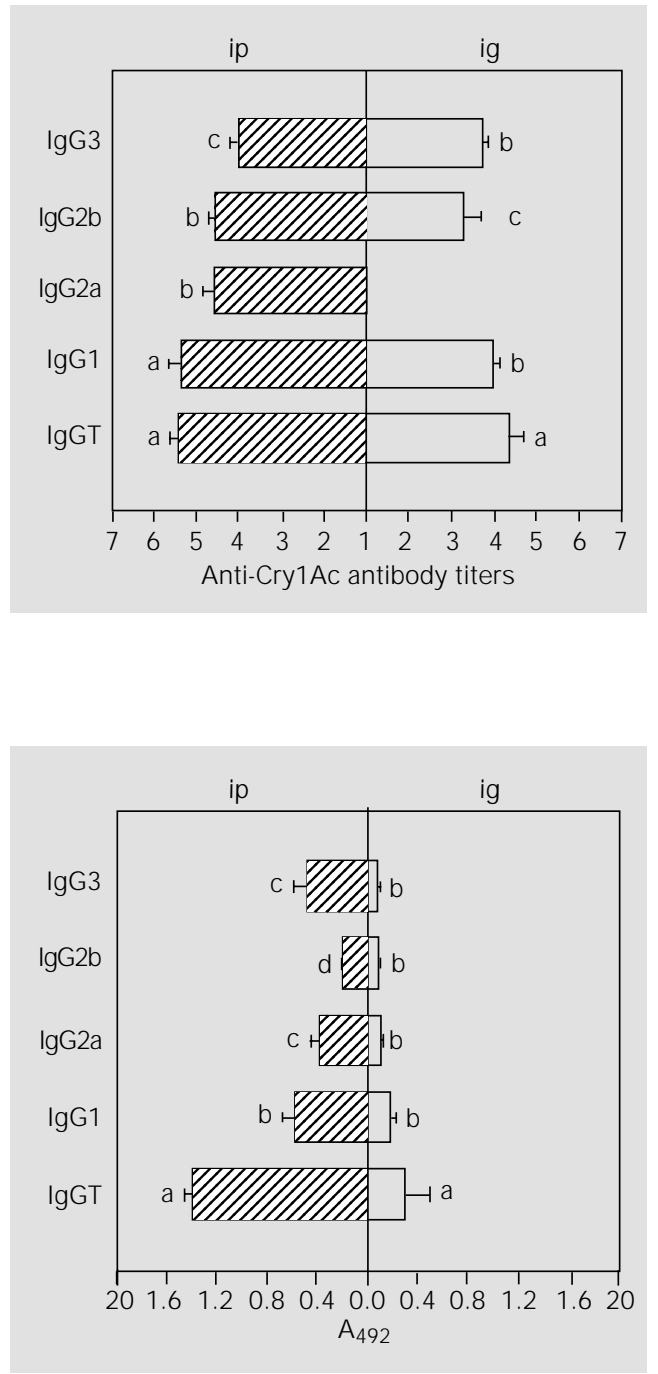

Figure 4 - Subclasses of antipCrylAc IgG coproantibodies in the small intestinal fluids after ip or ig immunization with 100 $\mu \mathrm{g}$ of pCrylAc. The mean $\mathrm{A}_{492}$ values of nonimmunized mice were $0.073 \pm 0.01$. Bars represent the level of antibodies reported as arbitrary units of $A_{492}$ \pm SD for each experimental group $(\mathrm{N}=5)$. The letters on top of the bars represent the differences observed by the Newman-Keuls test $(P<0.01)$.

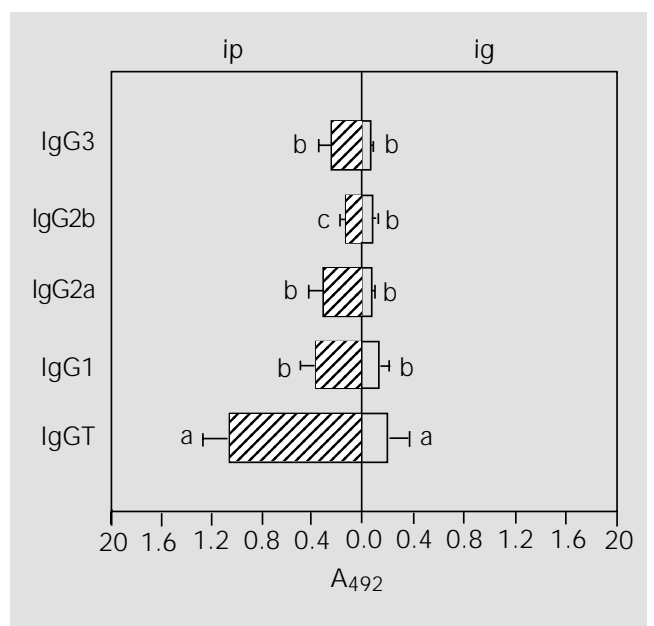

induced $2.8 \times 10^{3}, 0.6 \times 10^{3}$ and $7.55 \times 10^{3}$ IgG specific SFC per $10^{7}$ cells in Spl, MLN and $P P$, respectively. Antibodies were found only in PP plasma cells producing antipCry $1 \mathrm{Ac} \operatorname{IgA}\left(3.03 \times 10^{2}\right)$ and $\operatorname{IgM}(18.62 \times$ $10^{2}$ ). In mice immunized $i g$, SFC values of $16.00 \times 10^{2}$ cells for IgA, $111.21 \times 10^{2}$ cells for $\mathrm{IgG}$ and $4.64 \times 10^{2}$ cells for IgM were obtained for PP, which were higher than those obtained by the ip route. These mice had a strong induction of pCry1Ac-specific IgA-producing $\left(1.41 \times 10^{2}\right) \mathrm{SFC}$ in the Spl. Moderate levels of plasma cells producing anti-pCry1Ac antibodies were detected in the MLN of mice immunized by both routes (Figure 5).

The pCry1 Ac-specific SFC present in the LP of small and large intestines were also quantified. When pCry1 Ac was applied ig or $i p$, IgA- and IgG-producing pCrylAc-specific SFC were obtained in LP lymphocytes from the small intestine. However, only plasma cells producing IgG antibodies were found in the large intestine (Figure 5).

\section{Immunogenicity of tCry1AC}

The Cry1 Ac toxin was administered to mice ip or ig to study its immunogenicity. When administered $i p$, tCry1 Ac induced serum antibody titers of 2.45 for IgA, 4.45 for IgG and 3.25 for IgM, which were lower than those obtained with the protoxin. Similar antibody levels were observed when the same toxin was applied ig (Figure 6).

The mucosal immune response induced by tCry1Ac was measured in the small and large intestinal fluids. In contrast to the protoxin, tCry1 Ac only induced anti-tCry $1 \mathrm{Ac}$ IgA antibodies in the small intestine, with higher levels when the antigen was applied $i p$. Specific antibodies were not detectable in fluids from the large intestine (Figure 6).

\section{Discussion}

We have previously reported that 
pCry $1 \mathrm{Ac}$ is able to induce a strong mucosal and systemic immune response in mice when applied by the ip or ig route (6). The present study provides further characterization of the mucosal and systemic immune responses induced by this antigen.

As expected, the kinetics of the serum antibody response induced by pCry1Ac by both immunization routes proved to be thymus dependent, with a strong induction of specific IgM antibodies after the first immunization and a good immunological memory of the protoxin.

The serum anti-pCry1Ac antibody titers induced by ig administration were lower than those obtained by ip administration, but the maximum and minimum values were obtained at the same times. These data show that the serum immune response induced against pCry1Ac was independent of the immunization route, and therefore we assume that this protein goes through the intestinal mucosa and is processed in the peripheral lymphoid organs to generate a systemic immune response. However, more experiments are necessary to test this hypothesis. The ability to induce serum antibody responses by oral immunization has been observed for other proteins like cholera (21) and Shiga toxins (22), both able to bind to the intestinal surface.

The immune response generated against pCry1Ac in the mucosal tissue supports the dichotomy existing between the systemic and mucosal immune systems. Significant levels of anti-pCry1Ac coproantibodies in feces were found after the last immunization by both routes. Administration of the protoxin by the ip route induced higher levels of specific IgG antibodies in feces than those obtained by the ig route. However, the highest levels of anti-pCry1Ac IgA antibodies were attained after ig administration. In contrast to the systemic immune response, our data show that the local response against pCry $1 \mathrm{Ac}$ is dependent on the administration route.
The ip route was as efficient as the ig route in triggering an anti-Cry $1 \mathrm{Ac}$ intestinal immune response. We rule out the possibility that the immune reaction induced by ip administration was a product of cross-reaction with intestinal bacterial antigens because the nonimmunized mice did not produce mucosal or serum anti-pCry1 Ac antibodies. These findings agree with data recently published on the characterization of
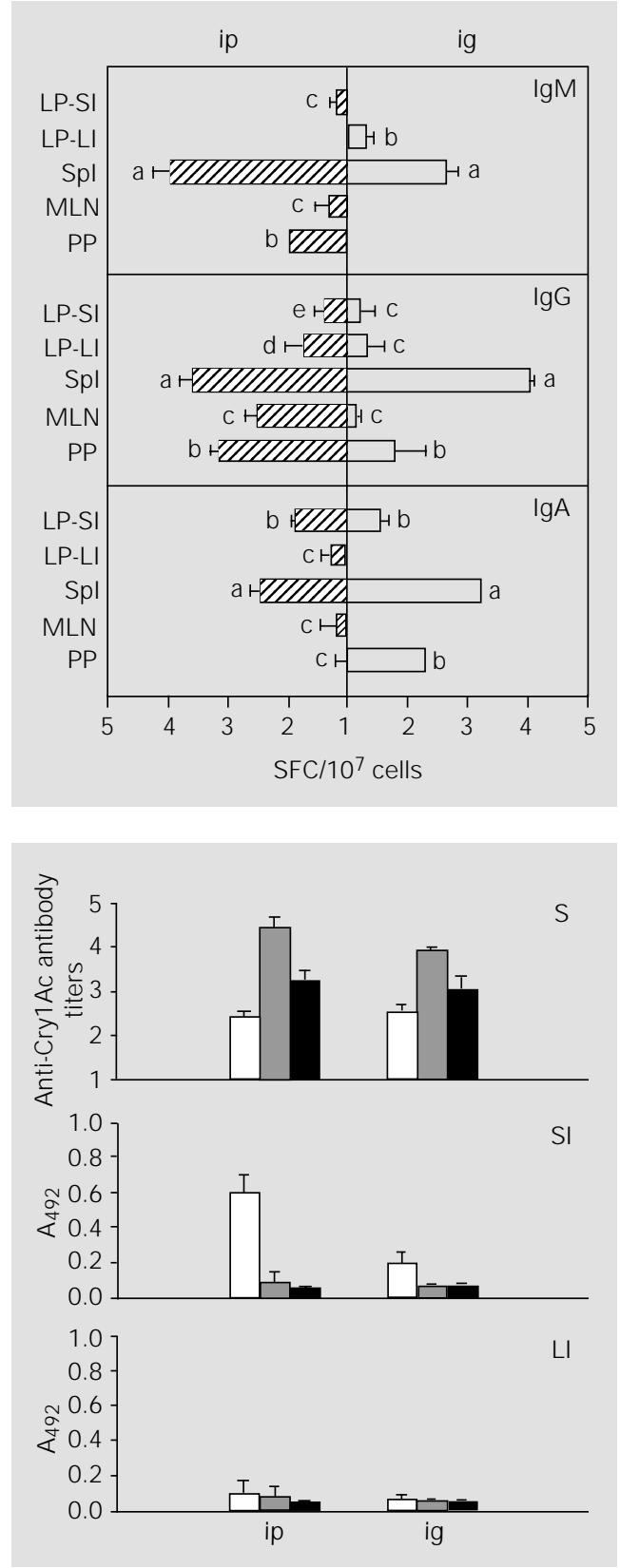

Figure 5 - Anti-pCrylAc antibody-producing cells (SFC) in the spleen (Spl), mesenteric lymph nodes (MLN), Payer's patches (PP) and lamina propria of the small (LP-SI) and large (LP-LI) intestine after ip or ig immunization with $100 \mu \mathrm{g}$ of pCrylAc. The numbers of SFC detected in nonimmunized mice were subtracted from each SFC value for immunized mice. Bars represent the means of SFC \pm SD for each experimental group $(\mathrm{N}=5)$. The letters on top of the bars represent the differences observed by the Newman-Keuls test $(P<0.01)$.

Figure 6 - Anti-tCrylAc antibody production in mice immunized by the ip or ig route. The levels of IgM (open bars), IgG (gray bars) and IgA (black bars) antibodies were determined in serum (S) and in the fluid of the small (SI) and large intestine (LI) by ELISA. Nonimmunized mice showed serum antibody titers $<1$ and intestinal contents with $\mathrm{A}_{492}<0.073 \pm 0.031$. Bars represent the level of antibodies \pm SD for each experimental group $(\mathrm{N}=5)$. 
the humoral and mucosal immune responses induced by pCry1Ac in mice (6). For other antigens, the ip route has proved to be effective in the induction of both systemic and mucosal immune responses (23) because the peritoneal cavity is known to be an important source of plasma cells that are later found in the mucosal tissues (24).

One of the main characteristics of pCry $1 \mathrm{Ac}$ is its ability to induce secretion of anti-pCry $1 \mathrm{Ac}$ IgG antibodies into the intestinal fluids. In the present paper, we show that these antibodies are mainly of the IgG1 subclass in both serum and intestinal fluids of immunized mice. However, there was a remarkable difference between the IgG-subclass antibodies present in serum and those in the intestinal fluids, which suggests that the production of coproantibodies occurred locally and that serum antibodies are poorly transferred through the corresponding mucosae. These data and the absence of hemoglobin in the intestinal fluids led us to exclude the possibility of serum contamination.

The presence of IgG antibodies is frequently associated with inflammatory diseases such as chronic gastritis and celiac disease; however, the innocuousness of Cry proteins to vertebrates has been well demonstrated (25). Toxicity studies submitted to the US Environmental Protection Agency have provided evidence that $B$. thuringiensis preparations containing a high concentration of Cry proteins and free of B-exotoxin have no significant adverse effects on laboratory mice and rats. Mayes et al. (26) did not detect intestinal inflammation when they administered Cry $1 \mathrm{Ac}$ protein orally to mice. The role of non-IgA isotypes in the mucosal immune response is still unclear. It has been found that locally synthesized specific IgG antibodies contribute to immunity against viral and bacterial infections $(27,28)$. Recently, Berneman et al. (28) demonstrated the presence of mucosal $\mathrm{IgG}$ antibodies against Streptococcus pyrogenes in healthy humans.

The distribution of pCry1 Ac-specific an- tibody-producing cells was studied using the ELISPOT technique. The specific antibodies generated after mucosal or systemic immunization were produced by different lymphoid sites inside and outside the gut-associated lymphoid tissue. The presence of pCry1Ac-specific SFC in PP, MLN and LP from mice immunized via ig is good evidence that pCry1 Ac activates B cells in PP which migrate to the MLN, then to the thoracic duct, and finally to the intestinal LP (29). As expected, ip immunization induced significant levels of pCry1 Ac-specific plasma cells in the lymphoid tissues studied. Considering these data as a whole, we conclude that the IgG and IgA antibodies secreted in the intestinal fluids are produced to a great extent by plasma cells present in the LP.

We found that tCrylAc was able to induce significant levels of specific antibodies in mouse serum and intestinal fluids when applied ig or ip. In contrast to the protoxin, anti-tCrylAc coproantibodies were of the IgA isotype and were only produced in the small intestine. The Cry1Ac toxin corresponds to the N-terminal domain of the protoxin, which has insecticidal properties. The tCry1Aa structure has been determined (30) and probably differs from the possible conformation adopted by the protoxin.

Transgenic plants containing high concentrations of Cry1A proteins have been commercialized for food production (8). Although it is known that these proteins are safe for animals and man, the high immunogenicity of Cry1A proteins administered ig should be taken into account before releasing Cry-containing products for human use. On the other hand, the present data support the idea that pCry1Ac may be used as a carrier to introduce vaccinal epitopes either parenterally or locally into the mucosal tissues. Cry proteins might therefore represent a valuable tool in mucosal immunity studies, particularly on the dynamics of intestinal IgG production and its role in the intestinal immune protection against infectious pathogens. 


\section{References}

1. Höfte $H \&$ Whiteley H (1989). Insecticidal crystal proteins of Bacillus thuringiensis. Microbiological Reviews, 53: 242-255.

2. Knowles B (1994). Mechanism of action of Bacillus thuringiensis insecticidal deltaendotoxin. Advances in Insect Physiology, 24: 275-307.

3. Carlson $C R$, Caugant $D A \&$ Kolsto $A B$ (1994). Genotypic diversity among Bacillus thuringiensis and Bacillus cereus strains. Applied and Environmental Microbiology, 60: 1719-1725.

4. Prasad SSSV \& Shethna YI (1976). Antitumor immunity against YAS after treatment with proteinaceous crystals of Bacillus thuringiensis. Indian J ournal in Experimental Biology, 14: 285-290.

5. Prasad SSSV \& Shethna YI (1975). Enhancement of immune response by the proteinaceous crystal of Bacillus thuringiensis. Biochemical and Biophysical Research Communications, 62: 517-521.

6. Vázquez-Padrón RI, Moreno-Fierros L, Neri-Bazán L, de la Riva GA \& LópezRevilla R (1999). Intragastric and intraperitoneal administration of CrylAc protoxin from Bacillus thuringiensis induce systemic and mucosal antibody response in mice. Life Sciences, 64: 1897-1912.

7. Vázquez-Padrón RI, Moreno-Fierros L, Neri-Bazán L, de la Riva GA \& LópezRevilla R (1999). Bacillus thuringiensis CrylAc protoxin is a potent systemic and mucosal adjuvant. Scandinavian J ournal of Immunology, 46: 578-584.

8. Koziel GM, Beland GL, Bowman C, Carozzi NB, Crenshaw R, Crossland L, Dawson J, Desai N, Hill M, Kadwell S, Launis K, Lewis K, Maddox D, McPherson K, Meghji M, Merlin M, Rhodes R, Warren GW, Wright M \& Evola S (1993). Field performance of elite transgenic maize plants expressing an insecticidal protein derived from Bacillus thuringiensis. Biotechnology, 11: 194-200.

9. Ge AZ, Pfister RM \& Dean DH (1990). Hyperexpression of a Bacillus thuringiensis delta-endotoxin-encoding gene in Escherichia coli: properties of the product. Gene, 93: 49-54.

10. Hofmann $C$, Lüthy $P$, Hütter R \& Pliska V (1988). Binding of the d-endotoxin from Bacillus thuringiensis to brush-border membrane vesicles of cabbage butterfly
(Pieris brassicae). European J ournal of Biochemistry, 173: 85-91.

11. Laemmli UK (1970). Cleavage of structural proteins during the assembly of the head of bacteriophage T4. Nature, 227: 680-685.

12. Bradford MM (1976). A rapid and sensitive method for the quantification of microgram quantities of proteins utilizing the principle of protein-dye binding. Analytical Biochemistry, 72: 248-254.

13. Coligan J E, Kruisbeek AM, Margulies DH, Saevach ET \& Struber W (Editors) (1996). Animal manipulation. In: Current Protocols in Immunology. 4th edn. J ohn Wiley $\&$ Sons, New York, 1.2.0-1.3.0.

14. Koertge TE \& Butler E (1986). Dimeric mouse IgA is transported into rat bile five times more rapidly than into mouse. Scandinavian J ournal of Immunology, 24: 567574.

15. Moreno-Fierros L, Domínguez MA \& Enríquez F (1995). Entamoeba histolytica: induction and isotype analysis of antibody producing cell responses in Payer's patches and spleen, after local and systemic immunization in male and female mice. Experimental Parasitology, 80: 541549.

16. Lycke N \& Holmgren J (1986). Intestinal mucosal memory and presence of memory cells in the lamina propria and Peyer's patches in mice 2 years after oral immunization with cholera toxin. Immunology, 59: 301-308.

17. Moreno-Fierros $L \&$ Lopez Revilla $R$ (1997). Rapid isolation of the large and small intestine to assess anti-Entamoeba histolytica immune response. Archives of Medical Research, 28: 253-255.

18. Bernice MM (1994). Tissue Culture Techniques. Birkhäuser, Boston.

19. Czerkinsky C, Nilsson L-A, Nygren $H$, Ouchterlony O \& Tarkowskil A (1983). A solid-phase enzyme-linked immunospot (ELISPOT) assay for enumeration of specific antibody-secreting cells. J ournal of Immunological Methods, 65: 109-121.

20. Sigarroa A (1985). Biometría y Diseño Experimental. Editorial Pueblo y Educación, La Habana.

21. Michalek SM, Eldridge J H, Curtiss III R \& Rosenthal KL (1994). Antigen delivery systems: New approaches to mucosal immu- nization. In: Ogra PL, Lamm ME, McGhee J R, Mestecky J , Strober W \& Bienestock J (Editors), Handbook of Mucosal Immunology. Academic Press, New York.

22. Keren DF, Brown JE, McDonald RA \& Wassef J S (1989). Secretory immunoglobulin A response to Shiga toxin in rabbits: kinetics of the initial mucosal immune response and inhibition to toxicity in vitro and in vivo. Infection and Immunity, 57: 1885-1889.

23. Solvason N, Lehuen A \& Kearney JF (1991). An embriogenic source of Lyl but not conventional B cells. International Immunology, 3: 543-550.

24. Murphy BR (1994). Mucosal immunity to viruses In: Ogra PL, Lamm ME, McGhee J R, Mestecky J , Strober W \& Bienestock J (Editors), Handbook of Mucosal Immunology. Academic Press, New York.

25. McClintock J T, Schaffer CR \& Sjoblad RD (1995). A comparative review of the mammalian toxicity of Bacillus thuringiensisbased pesticides. Pesticide Science, 45: 95-105.

26. Mayes ME, Held GA, Lau C, Seely J C, Roe RM, Dauterman WC \& Kawanishi R (1989). Characterization of the mammalian toxicity of the crystal polypeptides of Bacillus thuringiensis subsp israelensis. Fundamental and Applied Toxicology, 13: 310-316.

27. Suresh $P \&$ Arp LH (1995). Effect of passively administered immunoglobulin $\mathrm{G}$ on the colonization and clearance of Bordetella avium in turkeys. Veterinary Immunology and Immunopathology, 49: 229239.

28. Berneman A, Belec L, Fischetti VA \& Bouvet J -P (1998). The specificity patterns of human immunoglobulin $\mathrm{G}$ antibodies in serum differ from those in autologous secretions. Infection and Immunity, 66: 4163-4168.

29. Abreu-Martin MT \& Targan SR (1996). Regulation of immune response of the intestinal mucosa. Critical Reviews in Immunology, 16: 277-309.

30. Grochulski $\mathrm{P}, \mathrm{Masson} \mathrm{L}$, Borisova $\mathrm{S}$, Puztai-Carey M, Schawarts M, Brusseau R \& Cygler M (1995). Bacillus thuringiensis CrylA(a) insecticidal toxin: crystal structure and channel formation. J ournal of Molecular Biology, 254: 447-464. 